\title{
ANALYSIS OF SPERMATOZOA QUALITY USING PERCOLL DENSITY GRADIENT CENTRIFUGATION THROUGH THE ADMINISTRATION OF PHOSPHOLIPID + EGTA
}

\author{
ROOIJE R.H. RUMENDE ${ }^{1, *}$, EVA L. BAIDENG', \\ FREDINE E.S. RARES ${ }^{2}$, LAYA M. RARES ${ }^{3}$ \\ *E-mail: rooije.rumende@gmail.com
}

Received: Oct. 27, 2021. Revised: Dec. 19, 2021. Accepted: Feb. 04, 2022. Published online: Feb. 15, 2022

\begin{abstract}
The Percoll density gradient centrifugation (PDGC) method is frequently used in the sexing of spermatozoa. However, this method causes damage to the spermatozoa membranes, resulting in a decreased quality of spermatozoa. We analysed the impacts of phospholipid PC (phosphatidylcholine) and EGTA (ethylene glycol bis ( $\beta$-aminoethyl ether) $\mathrm{N}, \mathrm{N}, \mathrm{N}^{\prime}, \mathrm{N}^{\prime}$-tetraacetic acid) $\mathrm{Ca}^{2+}$ free buffer on the quality of bovine spermatozoa after the PDGC process, using semen from Friesian Holstein (FH) bulls aged 5 - 8 years. The following variables were observed: spermatozoa motility, spermatozoa viability, spermatozoamembraneintegrity, spermatozoa that have not experienced capacitation, spermatozoa that have experienced capacitation and spermatozoa that have undergone acrosomal reaction. The results showed that the administration of phospholipid PC + EGTA $\mathrm{Ca}^{2+}$ free buffer to spermatozoa, followed by the PDGC process, could maintain or further improve the values of all variables. In the PDGC process, phospholipid PC $10 \%+$ EGTA $\mathrm{Ca}^{2+}$ free buffer at $1 \mathrm{mM}$ was most suitable.
\end{abstract}

Keywords: PDGC; PC phospholipids; EGTA; separation spermatozoa.

\section{INTRODUCTION}

Separation of the $\mathrm{X}$ and $\mathrm{Y}$ chromosomes of spermatozoa can be carried out using the Percoll density gradient centrifugation (PDGC) method. This approach is easy in its implementation and application and a valid and inexpensive method. However, results from several recent studies indicate that the PDGC method may cause damage to spermatozoa membranes, which can further decrease the quality of spermatozoa (Susilawati et al., 2017).

Damage to the spermatozoa membrane after the PDGC process is caused by three factors, namely loss of seminal plasma, the presence of chemical factors characterised by an increase in free radicals, as well as physical factors that occur due to

\footnotetext{
${ }^{1}$ Department of Biology, Faculty of Mathematics and Natural Sciences, Sam Ratulangi University, Manado, Indonesia

2 Section of Microbiology, Faculty of Medicine, Sam Ratulangi University, Manado, Indonesia

${ }^{3}$ Section of Ophthalmology, Faculty of Medicine, Sam Ratulangi University, Manado, Indonesia
} 


\section{ANALYSIS OF SPERMATOZOA QUALITY USING PERCOLL DENSITY GRADIENT CENTRIFUGATION}

friction/collision between spermatozoa. Of the three factors, the physical factor is the most important one. It is therefore assumed that once this is fixed, the other factors are also neutralised. To fix the physical factor, the integrity of the spermatozoa membrane, which is composed of lipids, proteins, carbohydrates and other substances, is crucial (Tucker and Jansen, 2002).

Although the PDGC method has been widely used and is proven to be efficient, there are factors that limit the success of separating $\mathrm{X}$ and $\mathrm{Y}$ spermatozoa, namely the occurrence of damage to the spermatozoa membrane due to mechanical forces during the centrifugation and washing process of spermatozoa, which decreases the quality of spermatozoa. Inappropriate speed and duration of centrifugation during spermatozoa separation will decrease the viability and motility of spermatozoa (Rasad et al., 2019). In addition, centrifugation can cause the generation of Reactive Oxygen Species (ROS), namely an increase in free radicals due to membrane damage, affecting the physiological processes of spermatozoa (Zanella et al., 2016). Rasad et al. (2019), who performed sexing using the PDGC method, found a decrease in motility by $39.87 \%$ for $X$ spermatozoa and $34.73 \%$ for Y spermatozoa. This decrease occurred due to the influence of mechanical forces, the spermatozoa medium and the temperature during centrifugation. In addition, there was an increase in the percentage of abnormal spermatozoa due to collisions on the tube wall during the sexing process, resulting in damage to the morphology of spermatozoa.

To repair the damaged membrane structure, phospholipids have been administered based on the results of previous studies (Bowyer and Davies, 1979). Research has also been carried out on human spermatozoa by Djauhari (2009) through the addition of phospholipids in tris aminomethane diluent, which can maintain the quality of spermatozoa and increase the number of intact spermatozoa, inhibiting premature capacitation. In addition, Rumende et al. (2007) suggested that the addition of 10\% PPC phospholipid (pure phosphatidyl choline $97.5 \%$ ), in combination with the PDGC method, improved the quality of spermatozoa.

In bovine spermatozoa, damage to the structure of the spermatozoa membrane on the head, acrosomal hood or tail, caused by the PDGC process, affects the transport of calcium ions into and out of the spermatozoa membrane. An excessive increase in calcium ions in the cell causes the disruption of cell functions, resulting in a decreased quality of spermatozoa. Efforts to inhibit the entry of calcium ions into cells or to modulate the entry of calcium ions into cells, as well as attempts to conduct calcium chelation using various natural materials or more selective synthesis, have yielded promising results in the prevention and treatment of various diseases. For example, ethylene glycol bis ( $\beta$-aminoethyl ether)-N,N,N',N'tetraacetic acid (EGTA) $\mathrm{Ca}^{2+}$-free buffer is a scavenger of extracellular and intracellular $\mathrm{Ca}^{2+}$ ions that selectively binds $\mathrm{Ca}^{2+}$ with the highest affinity level $(150 \mathrm{nM}$ at $\mathrm{pH}$ 7.2) (Ellis-Davies and Kaplan, 1994; Lemonnier et al., 2002). Another study has shown that $1 \mathrm{mM}$ EGTA with free $\mathrm{Ca}^{2+}$ buffer in endothelial cell culture induced by various agonists, or administering $100 \quad \mathrm{M} \mathrm{H}_{2} \mathrm{O}_{2}$, may 


\section{ROOIJE R.H. RUMENDE, EVA L. BAIDENG, FREDINE E.S. RARES, LAYA M. RARES}

cause $\mathrm{Ca}^{2+}$ depletion from endoplasmic reticulum depots and inhibit $\mathrm{Ca}^{2+}$ infusion from extracellular depots. The EGTA is a scavenger of $\mathrm{Ca}^{2+}$ ions that selectively binds $\mathrm{Ca}^{2+}$ with high affinity (Hu and Corda, 1988; Sadova and Klishin, 2000; Parekh, 2002).

The purpose of this study was to reveal the effect of phospholipid PC (phosphatidyl choline) and EGTA (ethylene glycol bis ( $\beta$-aminoethyl ether)-N,N,N',N'-tetraacetic acid) $\mathrm{Ca}^{2+}$ free buffer on the quality of bovine spermatozoa after PDGC. The existence of $\mathrm{X}$ and $\mathrm{Y}$ chromosomes in the sexing results was not observed because this study was conducted only on the sexing process of spermatozoa and did not measure the separation of $\mathrm{X}$ and $\mathrm{Y}$ chromosomes. We looked at the impact of the sexing process on the quality of spermatozoa subjected to phospholipid + EGTA treatment. Based on previous studies, spermatozoa resulting from the sexing process generally show a decreased quality.

\section{MATERIALS AND METHODS}

This research was conducted at the Advanced Biology Laboratory, Department of Biology, Faculty of Math and Natural Sciences, Sam Ratulangi University, Manado, Indonesia. We used semen taken from 10 Friesian Holstein $(\mathrm{FH})$ bulls aged 5 - 8 years and managed by the Sehati Farmers Group in Kakaskasen Dua Village, North Tomohon Sub-district, assisted by the Agriculture and Fisheries Service of Tomohon City. Semen was taken twice from each bull. The criteria for good-quality fresh semen were as follows: per-ejaculate volume ranging from $5-8 \mathrm{~mL}$ and concentrations between 700 and 2,000 million sperm per mL (Garner and Hafez, 2000; Berden and
Fuquay, 1984). Also, semen with a motility percentage above $70 \%$ is more viable than that with lower motility (Susilawati et al., 2017). Thishas been supported by otherstudies: motility of at least $70 \%$ (Zenichiro et al., 2002), motility $>70 \%$ and $\mathrm{pH}$ level of 5.9 7.3 (Hafez, 2000); viability $>80 \%$ (Ax et al., 2000) and membrane integrity level of $72.90 \%$ (Check et al., 1992).

This research is a laboratory experimental study using phospholipid PC $10 \%+$ EGTA $\mathrm{Ca}^{2+}$ free buffer $(0.5 \mathrm{mM}$, $1 \mathrm{mM}, 2 \mathrm{mM}$ ), administered prior to the PDGC process. After the PDGC, the following variables were observed: spermatozoa motility, spermatozoa viability, spermatozoa membrane integrity, spermatozoa not capacitated, spermatozoa capacitated, spermatozoa subjected to acrosomal reaction. Statistical analysis was done using one-way classification analysis of variance (ANOVA) to determine which level had the best significance for each variable, followed by the LSD test to determine the significance between untreated spermatozoa and control spermatozoa after PDGC. Duncan's multiple distance test was performed to determine the effect of each level on each variable. Data were analysed using the software package SPSS (Statistical Product and Service Solutions) version 22. Significance was set at $0.05(p \leq 0.05)$.

\section{Percoll density gradient centrifugation method}

\section{Making a Percoll density gradient}

The density gradients used were 1.036 , $1.038,1.043,1.047,1.052,1.055,1.057,1.060$, 1.065 and 1.070 , obtained by diluting Percoll with Tris aminomethane phospholipid (Djati, 2005: $80 \mathrm{~mL}$ Tris aminomethane, $20 \mathrm{~mL}$ phospholipid PC) to the density levels of 20 , $25,30,35,40,45,50,55,60$ and $65 \%$, respectively. Subsequently, of each sample, an aliquot of $0.5 \mathrm{~mL}$ was taken and placed into a tube, arranged sequentially from the highest to the lowest density level. 


\section{ANALYSIS OF SPERMATOZOA QUALITY USING PERCOLL DENSITY GRADIENT CENTRIFUGATION}

\section{Centrifugation}

For this, $1 \mathrm{~mL}$ of the sample was placed into a tube containing a Percoll density gradient and centrifuged at $2,250 \mathrm{rpm}(850 \mathrm{~g})$ for 5 minutes. The obtained top layer was the seminal plasma, which was removed from the tube and second layer contained the Y spermatozoa. The third layer contained the $\mathrm{X}$ spermatozoa, which were taken out and placed into a tube containing $4 \%$ FBS in TCM 199, at a total volume of $3 \mathrm{~mL}$, followed by centrifugation at $1,500 \mathrm{rpm}(380 \mathrm{~g})$ for 5 minutes. Subsequently, the supernatant was discarded, and a liquid containing the spermatozoa was obtained, of which $1 \mathrm{~mL}$ was taken. After treatment via PDGC for 30 minutes, the sample was stained for 15 minutes, followed by observing the quality of the spermatozoa.

\section{Making coloring material}

Eosin-Negrosin, as the staining agent in the viability test, was made by dissolving $1 \mathrm{~g}$ of eosin, $5 \mathrm{~g}$ of negrosin and $3 \mathrm{~g}$ of sodium citrate in $100 \mathrm{~mL}$ of distilled water.

Chlortetracycline (CTC) was made through the following steps: (1) $250 \mathrm{~g}$ of DABCO (Sigma, D-2522) was dissolved in $9 \mathrm{~mL}$ of glycerol and incubated in a waterbath at $37^{\circ} \mathrm{C}$ for $3-4$ hours. After this, $1 \mathrm{~mL}$ of PBS was added, and the mixture was stored in a freezer; (2) $0.2422 \mathrm{~g}$ of Tris (Trisma base; Sigma T-1503) and $0.7592 \mathrm{~g}$ of $\mathrm{NaCl}$ were dissolved in $100 \mathrm{~mL}$ of deionised water and stored in a refrigerator; (3) $6.057 \mathrm{~g}$ of Tris was dissolved in $59 \mathrm{~mL}$ of deionised water and stored in a refrigerator; (4) $12.5 \mathrm{~g}$ of paraformaldehyde was dissolved in $50 \mathrm{~mL}$ of deionised water, followed by adding $1 \mathrm{M}$ of $\mathrm{NaOH}$ until the colour became lighter; (5) the solution obtained from the fourth stage was mixed with $1 \mathrm{M}$ tris buffer solution obtained from the third stage at a ratio of $1: 1$ (the $\mathrm{pH}$ was adjusted to 7.4 with $0.2 \mathrm{M} \mathrm{HCl}$ ) and stored in a refrigerator; (6) $0.0044 \mathrm{~g}$ of CTC powder dye (Sigma, C-7880) was mixed with $0.22 \mathrm{~g}$ of L-cysteine (hydrochloric monohydrate); the mixture was mixed with $5 \mathrm{~mL}$ of CTC buffer from the second stage ( $\mathrm{pH}$ was adjusted to 7.8 with $0.2 \mathrm{M} \mathrm{HCl}$ ). Finally, three solutions were obtained, namely DABCO solution (stored in a freezer), CTC fixative solution (stored in a refrigerator) and CTC dye solution (stored in a refrigerator).

The hypoosmotic swelling test was performed by making a 150-m-osmos hypoosmotic solution that contained $7.35 \mathrm{~g}$ of sodium citrate $2 \mathrm{H}_{2} \mathrm{O}$ and $13.52 \mathrm{~g}$ of fructose, dissolved in $1,000 \mathrm{~mL}$ of distilled water. The phospholipid PPC (pure phosphatidyl choline $97.5 \%$ ) was obtained from Viva.

\section{Spermatozoa motility observation}

Briefly, $10 \mu \mathrm{L}$ of spermatozoa was dropped onto a concave glass object, covered with a glass cover measuring $22 \times 22 \mathrm{~mm}$ and observed under a light microscope with 400x magnification using computer-assisted semen analysis (CASA). At least 200 motile spermatozoa were observed and divided into four groups: very good movement, good movement, non-progressive movement and not moving. The data obtained were used as a comparison in the observation of spermatozoa motility using CASA (Hafez, 2000).

\section{Spermatozoa viability observations}

The semen was dripped with 1 drop of eosin-negrosin solution, placed on a glass object, homogenised, smeared and dried. Observationswere made under a light microscope with a magnification level of 400x. As shown in Fig. 1, only living spermatozoa absorbed the colour (Hafez, 2000).

\section{Capacitation observation}

The method used to observe capacitation was based on Djati (2005), who modified the Fraser method as follows: (1) $100 \mu \mathrm{L}$ of semen was placed in a $1.5-\mathrm{mL}$ Eppendorf tube and mixed with $45 \mu \mathrm{L}$ of CTC dye solution. Subsequently, the tube was covered with aluminium foil and vortexed for 1 minute; (2) $8 \mu \mathrm{L}$ of CTC fixative was added into the Eppendorf tube, and the mixture was vortexed for 1 minute; 
(3) $10 \mu \mathrm{L}$ of DABCO was added into the Eppendorf tube and mixed carefully; (4) the Eppendorf tube was then covered with a cover glass and thick tissue paper, which were pressed carefully. The edges of the cover glass were covered with nail polish to protect the solution from drying. Observations were made with an epifluorescence microscope (Nikon) with 400x magnification. The characteristics are shown in Fig. 2. Spermatozoa that had not experienced capacitation showed a light colour on the entire head, whereas spermatozoa that had experienced capacitation showed a light colour only on the upper half of the head. Spermatozoa subjected to acrosomal reaction showed either a light colour or a circular ring appearance at the central part of the head.

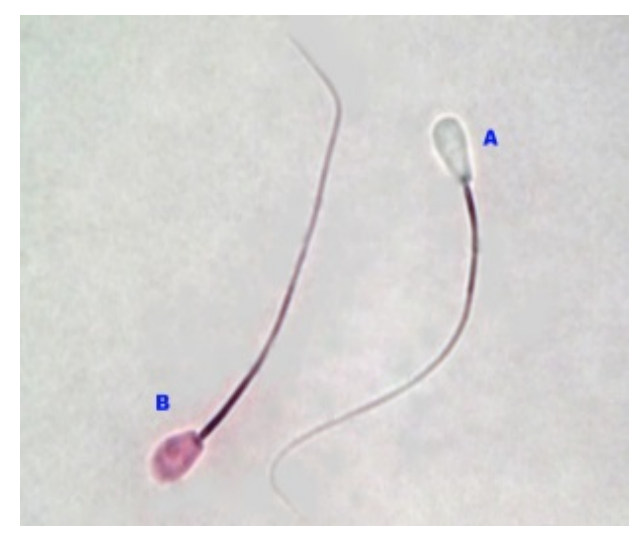

\section{Notes:}

(A) Living spermatozoa (do not absorbe the dye); (B) Dead spermatozoa (absorbed the dye)

Figure 1 - Observation of spermatozoa viability with Eosin-Negrosin using a light microscope (OLYMPUS) with 1000X magnification

\section{Observation of membrane integrity with hypoosmotic swelling test}

For this, $1 \mathrm{~mL}$ of a $150-\mathrm{mL}$ osmotic hypoosmotic solution was added to $0.1 \mathrm{~mL}$ of spermatozoa and the mixture was incubated at $370^{\circ} \mathrm{C}$ for 30 minutes. As shown in Fig. 3, when observed at 400x magnification, there was a characteristic membrane damage, namely swelling of the spermatozoa or a circular tail end (Correa et al., 1997).
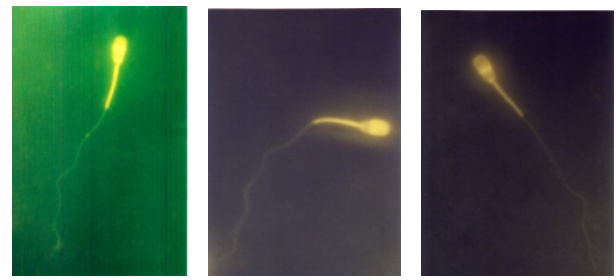

Notes: (A) Uncapacitated spermatozoa;

(B) Capacitated spermatozoa; (C) Spermatozoa that have undergone acrosomal reaction

Figure 2 - Observation of the physiological conditions of spermatozoa after CTC staining using epifluorescence microscope (NIKON) with 400x magnification

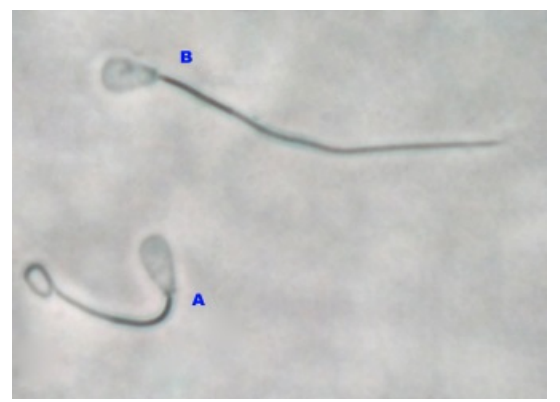

Notes: (A) The coiled spermatozoa are those with intact membrane integrity;

(B) Spermatozoa without a coiled shape are those with damaged membrane integrity

Figure 3 - Observation of the spermatozoa membrane integrity using a light microscope (OLYMPUS)

\section{RESULTS AND DISCUSSION}

\section{Fresh semen quality}

The fresh semen samples that were taken from 10 Friesian Holstein $(\mathrm{FH})$ bulls did not contain abnormal sperm, as shown in Table 1.

Based on the examination of the quality of fresh semen (Table 1), the semen was normal. The per-ejaculate volume ranged from 5 - $8 \mathrm{~mL}$, with concentrations between 700 and 2,000 million sperm 


\section{ANALYSIS OF SPERMATOZOA QUALITY USING PERCOLL DENSITY GRADIENT CENTRIFUGATION}

per mL (Garner and Hafez, 2000; Berden and Fuquay, 1984). According to the viability indicators, the semen may be used for further treatment.

\section{Effect of Percoll density gradient centrifugation on cow spermatozoa quality}

The results of the statistical analysis (Fig. 4) showed that the percentage of spermatozoa quality for all tested variables, using the PDGC method, decreased significantly (LSD test $p \leq 0.001)$, when compared with the control (without PDGC).

In other words, the PDGC method significantly decreased the quality of spermatozoa in all variables studied.

Table 1 - Results of quality inspection of fresh semen taken from 10 Friesian Holstein (FH) bulls before treatment with phospholipid 10\%+EGTA Ca ${ }^{2+}$ free buffer (0.5 mM, $\left.1 \mathrm{mM}, 2 \mathrm{mM}\right)$

\begin{tabular}{lc}
\hline Parameter & Mean \pm SD \\
\hline Volume $(\mathrm{ml})$ & $9.71 \pm 0.95$ \\
\hline $\mathrm{pH}$ & $6.30 \pm 0.08$ \\
\hline Concentration $\left(10^{6}\right)$ & $1518.70 \pm 303.25$ \\
\hline Motility $(\%)$ & $75.00 \pm 0.00$ \\
\hline Viability $(\%)$ & $93.15 \pm 2.78$ \\
\hline Membrane integrity $(\%)$ & $74.99 \pm 4.13$ \\
\hline Uncapacitated spermatozoa (\%) & $54.09 \pm 4.61$ \\
\hline Capacitated spermatozoa (\%) & $31.39 \pm 2.92$ \\
\hline Acrosomal reaction spermatozoa & $14.51 \pm 4.71$ \\
\hline
\end{tabular}

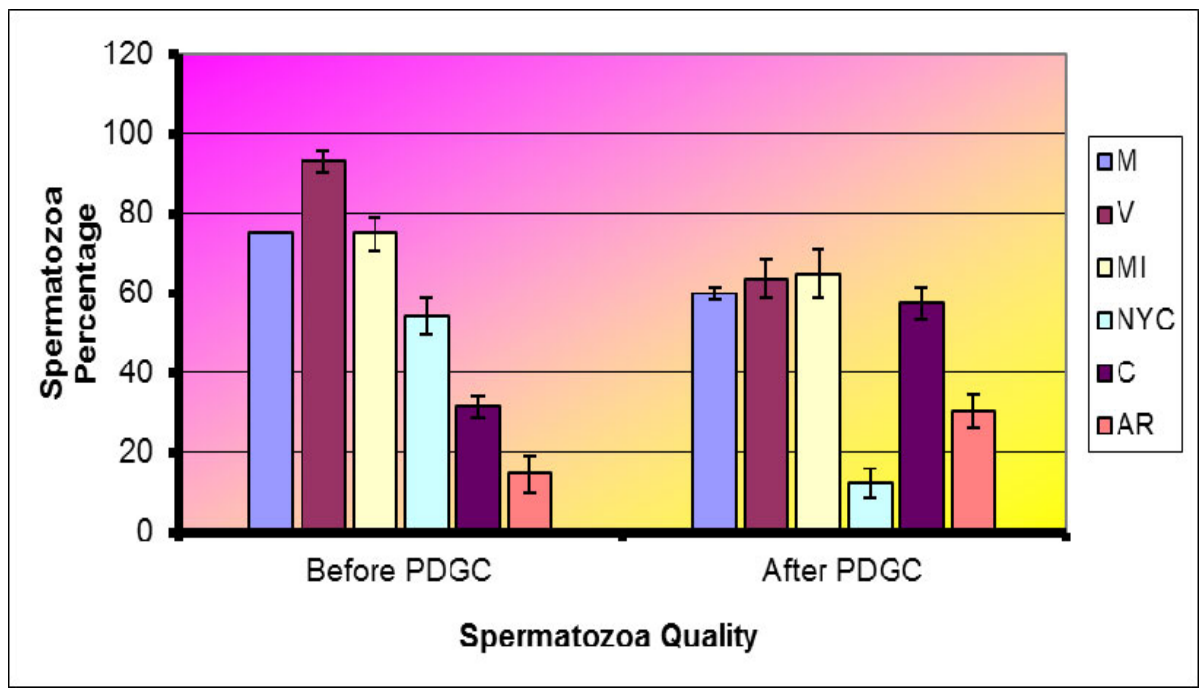

Notes: Motility (M), Viability (V), Membrane Integrity (MI), Not yet capacitated (NYC), Capacitated (C), Acrosomal reaction (AR)

Figure 4 - Percentage \pm SD of all variables before PDGC treatment and after PDGC treatment (LSD test results, $p \leq 0.01$ ) 
Effect of PC phospholipids $10 \%+$

EGTA Ca2 + free buffer $(0.5 \mathrm{mM}, 1$ $\mathrm{mM}, 2 \mathrm{mM}$, respectively) on spermatozoa after PDGC

Based on the results, the administration of $10 \%$ PC phospholipid concentration + EGTA $\mathrm{Ca}^{2+}$ free buffer $(0.5,1$ and $2 \mathrm{mM})$ in spermatozoa through the PDGC method, the spermatozoa quality in each variable spermatozoa motility (Fig. 5), spermatozoa viability (Fig. 6), spermatozoa membrane integrity (Fig. 7), spermatozoa that have not experienced capacitation (Fig. 8), spermatozoa that have experienced capacitation (Fig. 9) and spermatozoa that have undergone acrosomal reaction (Fig. 10) increased significantly (ANOVA result $p \leq 0.001$ ), when compared with the control variables. In addition, the administration of PC phospholipid 10\% concentration + EGTA $\mathrm{Ca}^{2+}$ free buffer at $1 \mathrm{mM}$ resulted in a more significant effect when compared to the other levels ( 0.5 or $2 \mathrm{mM})$.

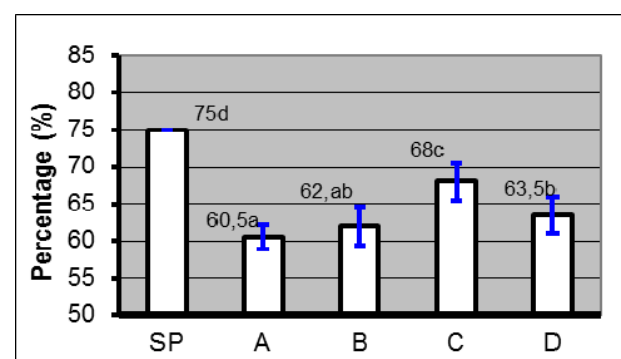

Notes: $\mathrm{SP}=$ Before treatment; $\mathrm{A}=$ Phospholipids $0 \%$ + EGTA Ca ${ }^{2+}$ free buffer $(0 \mathrm{mM}) ; \mathrm{B}=$ Phospholipid $10 \%+\mathrm{EGTA} \mathrm{Ca}^{2+}$ free buffer $(0.5 \mathrm{mM})$; $\mathrm{C}=$ Phospholipid $10 \%+$ EGTA Ca ${ }^{2+}$ free buffer (1 mM); D=Phospholipids $10 \%+E_{\text {GTA Ca }}{ }^{2+}$ free buffer (2 mM); (a, b, c); Duncan's multiple distance test results $5 \%$

Figure 5 - Average percentage \pm SD of motility before and after treatment with phospholipids + EGTA Ca ${ }^{2+}$ free buffer

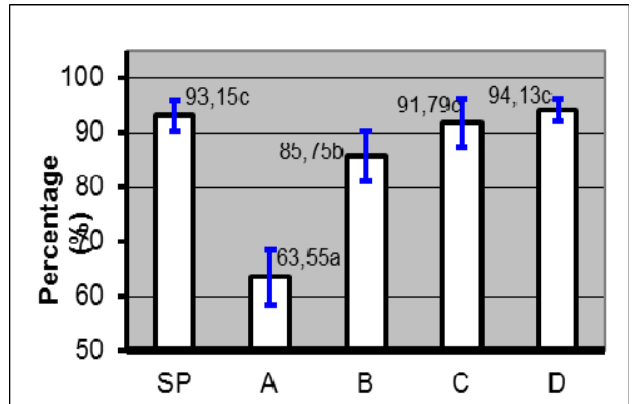

Notes: $\mathrm{SP}=$ Before treatment; $\mathrm{A}=$ Phospholipids $0 \%$ + EGTA Ca ${ }^{2+}$ free buffer (0 mM); B=Phospholipid $10 \%+E^{-} \mathrm{ETA} \mathrm{Ca}^{2+}$ free buffer $(0.5 \mathrm{mM})$;

$\mathrm{C}=$ Phospholipid $10 \%+\mathrm{EGTA} \mathrm{Ca}^{2+}$ free buffer (1 mM); D=Phospholipids $10 \%+E G T A \mathrm{Ca}^{2+}$ free buffer (2 mM); (a, b, c)=Duncan's multiple distance test results $5 \%$

Figure 6 - Average percentage \pm SD viability before and after treatment with phospholipids + EGTA Ca ${ }^{2+}$ free buffer

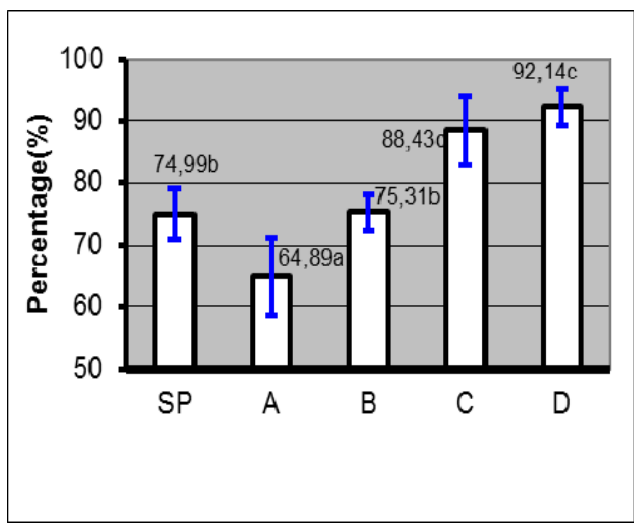

Notes: $\mathrm{SP}=\mathrm{Before}$ treatment; $\mathrm{A}=\mathrm{Phospholipids} 0 \%$ + EGTA Ca ${ }^{2+}$ free buffer $(0 \mathrm{mM}) ; \mathrm{B}=$ Phospholipid $10 \%+E G T A \mathrm{Ca}^{2+}$ free buffer $(0.5 \mathrm{mM})$; $\mathrm{C}=$ Phospholipid $10 \%+\mathrm{EGTA} \mathrm{Ca}^{2+}$ free buffer (1 mM); D=Phospholipids $10 \%+E_{\text {GTA Ca }}{ }^{2+}$ free buffer (2 mM); (a, b, c)=Duncan's multiple distance test results $5 \%$

Figure 7 - Average percentage \pm SD of membrane integrity before and after treatment with phospholipids + EGTA $\mathrm{Ca}^{2+}$ free buffer 


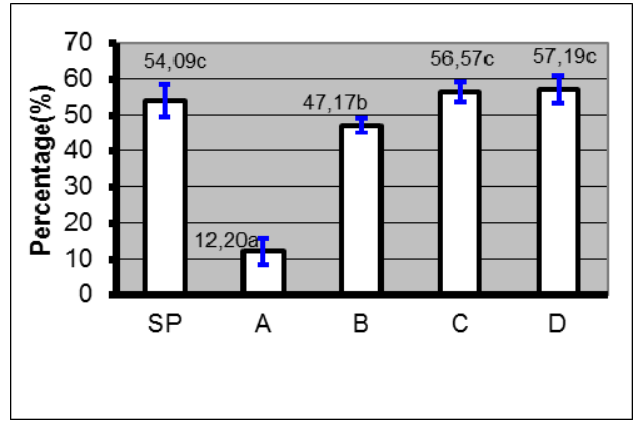

Notes: $\mathrm{SP}=\mathrm{Before}$ treatment; $\mathrm{A}=\mathrm{Phospholipids} 0 \%$ + EGTA Ca ${ }^{2+}$ free buffer $(0 \mathrm{mM}) ; \mathrm{B}=$ Phospholipid $10 \%+\mathrm{EGTA} \mathrm{Ca}^{2+}$ free buffer $(0.5 \mathrm{mM})$; C=Phospholipid 10\% + EGTA Ca ${ }^{2+}$ free buffer (1 mM); D=Phospholipids $10 \%+E G T A \mathrm{Ca}^{2+}$ free buffer (2 mM); (a, b, c)=Duncan's multiple distance test results $5 \%$

Figure 8 - Average percentage \pm SD of uncapacitated spermatozoa before and after treatment with phospholipids + EGTA $\mathrm{Ca}^{2+}$ free buffer

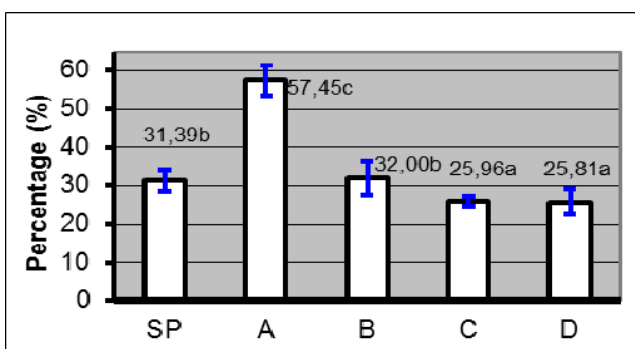

Notes: $\mathrm{SP}=\mathrm{Before}$ treatment; $\mathrm{A}=\mathrm{Phospholipids} 0 \%$ + EGTA Ca ${ }^{2+}$ free buffer $(0 \mathrm{mM})$; $B=$ Phospholipid $10 \%+\mathrm{EGTA} \mathrm{Ca}^{2+}$ free buffer $(0.5 \mathrm{mM})$; $\mathrm{C}=$ Phospholipid $10 \%+$ EGTA Ca ${ }^{2+}$ free buffer (1 mM); D=Phospholipids $10 \%+E_{\text {ETA Ca }}{ }^{2+}$ free buffer (2 mM); (a, b, c)=Duncan's multiple distance test results $5 \%$

Figure 9 - Average percentage \pm SD of capacitated spermatozoa before and after treatment with phospholipids + EGTA $\mathrm{Ca}^{2+}$ free buffer

Based on the obtained results, the improvement of spermatozoa quality in all study variables after the administration of $10 \%$ PC phospholipid concentration + EGTA $\mathrm{Ca}^{2+}$ free buffer at either $0.5,1$ or $2 \mathrm{mM}$ was caused by a significant positive effect of PC phospholipids on spermatozoa quality; the balance of the calcium ion concentration between inside and outside the cell was well maintained through the administration of EGTA $\mathrm{Ca}^{2+}$ free buffer. The EGTA $\mathrm{Ca}^{2+}$ free buffer functions as a scavenger of extracellular and intracellular $\mathrm{Ca}^{2+}$ ions and selectively binds $\mathrm{Ca}^{2+}$, with the highest affinity level of $150 \mathrm{nM}$ at pH 7.2.

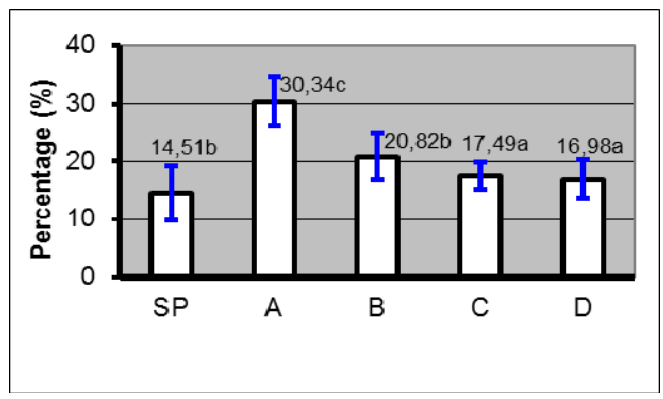

Notes: $\mathrm{SP}=\mathrm{Before}$ treatment; $\mathrm{A}=\mathrm{Phospholipids} 0 \%$ + EGTA Ca ${ }^{2+}$ free buffer $(0 \mathrm{mM}) ; \mathrm{B}=$ Phospholipid $10 \%+E^{-E T A ~ C a}{ }^{2+}$ free buffer $(0.5 \mathrm{mM})$; $\mathrm{C}=$ Phospholipid $10 \%+\mathrm{EGTA} \mathrm{Ca}^{2+}$ free buffer (1 mM); D=Phospholipids $10 \%+\mathrm{EGTA} \mathrm{Ca}^{2+}$ free buffer (2 mM); (a, b, c)=Duncan's multiple distance test results $5 \%$

Figure 10 - Average percentage \pm SD of spermatozoa that have undergone acrosome reaction before and after treatment with phospholipids + EGTA $\mathrm{Ca}^{2+}$ free buffer

The results are in agreement with the findings of Ellis-Davies and Kaplan (1994) and Lemonnier et al. (2002). In another study, $1 \mathrm{mM}$ EGTA with free $\mathrm{Ca}^{2+}$ buffer in an endothelial cell culture induced by various agonists or administration of $100 \mathrm{M} \mathrm{H} \mathrm{H}_{2} \mathrm{O}_{2}$ may cause $\mathrm{Ca}^{2+}$ depletion from endoplasmic reticulum depots and inhibits $\mathrm{Ca}^{2+}$ infusion from the extracellular matrix. In addition, EGTA was able to sharply reduce cytosolic $\mathrm{Ca}^{2+}$ with a long glucose exposure of 7 days. These results are in 
accordance with the findings of Hu et al. (1988), Sadova and Klishin (2000) and Parekh (2002). This contributed greatly to the increase in cytosolic $\mathrm{Ca}^{2+}$, and on day 7 of exposure, the increase in cytosolic $\mathrm{Ca}^{2+}$ was caused by influx from the extracellular matrix. Ellis-Davies and Kaplan (1994) obtained similar results.

Our findings support the hypothesis that the results obtained by other researchers may also be applied to spermatozoa cells. This is based on the understanding that calcium ions $\left(\mathrm{Ca}^{2+}\right)$ are present in the cell matrix, via molecule adhesion, inside cell membranes and inside cell organelles, either bound to protein receptors in the cytosol or free in the cytosol. The free calcium ion concentration inside the cell is only $10^{-7} \mathrm{M}$, whereas outside the cell, it is $10^{-3} \mathrm{M}$. This huge difference between the free calcium ion concentration in the cytoplasm and in the extracellular fluid causes an abundant flow of calcium ions into the cytoplasm when calcium ion channels both inside the cell and in the organelle membrane are opened. This assumption is supported by Carrafoli et al. (1990) and Dedman and Kaetzel (1998).

The concurrent role of PC phospholipids and EGTA $\mathrm{Ca}^{2+}$ free buffer in this study showed that the membrane remained stable and could function properly because PC phospholipids maintain and protect the spermatozoa membranes, including building structures and metabolic processes, whereas EGTA $\mathrm{Ca}^{2+}$ free buffer functions as a scavenger of extracellular and intracellular $\mathrm{Ca}^{2+}$ ions. Synchronisation of the role of PC phospholipids and EGTA $\mathrm{Ca}^{2+}$ free buffer minimises the possibility of extracellular matrix deformation and changes in the ion regulation system in spermatozoa membranes that are caused by the PDGC process. As a results, the membranes may function properly and ultimately, the quality of the spermatozoa is maintained or even improved. The mechanism underlying the increase in calcium ions in the cytoplasm is twofold: 1) calcium ions enter when the canal is opened due to changes in membrane voltage (voltage-operated calcium channel, VOCC) and 2) calcium ions enter when the canal is opened due to binding of the ligand with the receptor (receptor-operated calcium channel, ROCC).

The opening of these two types of channels will cause the entry of calcium ions from outside the cell into the cell because of the large concentration gradient. The second pathway is by opening the ion channels in the cell organelle membrane. This channel is an ROCC; when a ligand binds to a receptor on the membrane, it will cause the release of calcium ions from the organelle into the cell cytoplasm. Ion channels exist in two forms, namely in the closed and in the open state. In accordance with the findings of Breitbart and Naor (1999), calcium release-activated calcium channel (CRAC) is the main route of calcium entry in spermatozoa that do not have voltage-dependent calcium channels with a capacitive calcium entry (CCE) mechanism. This channel is related with the calcium deposition phase into the internal depot. The emptying of internal depots appears to increase the calcium permeability in the plasma membrane, which causes the calcium plateau in spermatozoa cells to be highly dependent on the concentration 


\section{ANALYSIS OF SPERMATOZOA QUALITY USING PERCOLL DENSITY GRADIENT CENTRIFUGATION}

of extracellular calcium. Cytosolic calcium release and CRAC activation are closely related to the important role of acrosome calcium in regulating various cell functions, which is in line with Breitbart and Spungin (1997).

Furthermore, the incoming calcium will cause the intracellular calcium levels to increase or will fill the calcium storage. In addition, ligand binding to certain receptors will produce secondmessenger IP3, which will bind to ROCC on the acrosome and cause the release of calcium into the cytoplasm. Increased levels of calcium in the cytosol will inhibit the ability of IP3 to activate the channel. The increased calcium level in the cytoplasm will enter the mitochondria, where calcium is used for various oxidative phosphorylation enzymes for ATP synthesis.

Calcium will also bind to various protein receptors in cells, including protein kinase $\mathrm{C}$. In the acrosomal membrane, there is also a transport system that requires energy to transport calcium into the acrosome. Calcium from the acrosome will bind to PLC phosphatidylinositol 4,5-bisphosphate (PIP2) - diacyglycerol (DAG), opening the plasma membrane so that calcium enters the cytoplasm. Calcium derived from the acrosome will affect CCE activity on the plasma membrane, which can enter through this pathway. Agonists that bind to certain receptors on the cell membrane will activate the PLC enzyme to cleave the PIP2 precursor molecule into DAG and inositol $(1,4,5)$ triphosphate (IP3). The DAG, which also acts as a second messenger, will stimulate the activity of protein kinase-C (PKC), whereas IP3 causes the release of calcium in the acrosome. The mechanism by which IP3 releases intracellular calcium involves its interaction with specific receptors on the acrosomal membrane and the opening of acrosomal calcium channels. These results are supported by the findings of Toole et al. (1996), Breitbart and Spungin (1997), Breitbart and Naor (1999), Dragileva et al. (1999) and Baker et al. (2000).

Based on the results, it can be concluded that the optimal phospholipid concentration of PC $10 \%+$ EGTA $\mathrm{Ca}^{2+}$ free buffer is $1 \mathrm{mM}$, which can be justified based on the following results: (1) the concentrations of phospholipid PC $10 \%+$ EGTA Ca $^{2+}$ free buffer 1 and $2 \mathrm{mM}$ have the same notation for variables: spermatozoa viability, spermatozoa membrane integrity, spermatozoa that have not experienced capacitation, spermatozoa that have experienced capacitation, and spermatozoa that have undergone acrosomal reaction; (2) phospholipid concentration of PC $10 \%+$ EGTA Ca ${ }^{2+}$ free buffer at a concentration of $1 \mathrm{mM}$ for spermatozoa motility variable, produced the best notation and was significantly different from the concentration of phospholipid PC 10\% + EGTA Ca ${ }^{2+}$ free buffer $2 \mathrm{mM}$.

\section{CONCLUSIONS}

Phospholipid PC $10 \%+\mathrm{Ca}^{2+}$ free buffer at $0.5,1$ and $2 \mathrm{mM}$, combined with PDGC, significantly improved the quality of spermatozoa. The optimal concentration regarding all variables was PC $10 \%+\mathrm{Ca}^{2+}$ free buffer at $1 \mathrm{mM}$.

It is necessary to develop an effective and accurate method to measure the movement of calcium ions in spermatozoa when treated with $10 \%$ PC phospholipid 
concentration + EGTA $\mathrm{Ca}^{2+}$ free buffer + FURA2-AM.

A proportion of $10 \% \quad \mathrm{PC}$ phospholipid concentration + EGTA $\mathrm{Ca} 2+$ free buffer $(1 \mathrm{mM})$ or $10 \% \mathrm{PC}$ phospholipid concentration + EGTA $\mathrm{Ca}^{2+}$ free buffer $(2 \mathrm{mM})$ can be used to obtain productive spermatozoa.

The best concentration of phospholipids found in this study may be recommended for breeding quality livestock with reproductive biology technology.

\section{REFERENCES}

Ax, R.L., Dally, M., Didion, B.A., Lenz, R.W., Love, C.C., Varner, D.D., Havez B. \& Bellin, M.E. (2000). Semen evaluation. In: Reproduction in Farm Animals, $7^{\text {th }}$ ed., E.S.E. Hafez and B. Hafez (Eds.), Lea and Febiger, Philadelphia, pp. 365-375.

Baker, H.W.G., Liu, D.Y. \& Martic, M.G. (2000). The human acrosome reaction. Asian J. Androl., 2(3): 172-178.

Bowyer, D.E. \& Davies, P.F. (1979). Effect of concentration of perfusing free fatty acid on arterial lipid synthesis in perfused normal and atherosclerotic rabbit aortas. Atherosclerosis, 31(4):409-419, DOI: 10.1016/0021-91 50(78)90136-3

Berden, H.J. \& Fuquay, J.W. (1984). Applied animal reproduction. $2^{\text {nd }}$ ed., Res Pub. Co., Inc. Prentice-Hall, Reston, Virginia.

Breitbart, H. \& Spungin, B. (1997). The biochemistry of the acrosome reaction. Mol. Hum. Reprod., 3(3): 159-202, DOI: https://doi.org/10.1093/molehr/3.3.195

Breitbart, H. \& Naor, Z (1999). Protein kinase in mammalian sperm capacitation reaction. Rev. Reprod., Sep.4(3): 151-159, DOI: 10.1530/ror. 0.0040151

Carrafoli, E., Chiesi, M. \& Gazzotti, P. (1990). The membrane carriers related, and membrane potential in human endothelial cells. Circulation, 13: 17191725.

Check, J.H., Katsoff, D., Rozak, J. \& Lurie, D. (1992). Effect of swim-up, Percoll and Sephadex sperm separation methods on the hypo-osmotic swelling test. Human Reprod., 7.(1): 109-111, DOI: 10.1093/oxfordjournals.humrep. a137540

Correa, J.R., Heersche, G. \& \& Zavos, P.M. (1997). Sperm membrane functional integrity and response of frozen-thawed bovine spermatozoa during hypoosmotic swelling test incubation at varying temperatures. Theriogenology, 47(3): 715-721, DOI: 10.1016/s0093691x(97)00029-0

Dedman, J.R. \& Kaetzel, M.A. (2012). Calcium as an intracellular second messenger. mediation by calciumbinding proteins - Chapter 7, Cell Physiology Source Book (4 ${ }^{\text {th }}$ ed.), 99109, DOI: 10.1016/B978-0-12-3877383.00007-X

Djati, M.S. (2005). Peran Buffer $\mathrm{NaHCO}_{3}$ pada BO Medium Dalam Menginduksi Kapasitasi, Reaksi Akrosom, Viabilitas Sperma, dan Penetrasi Sperma Terhadap Oosit pada Fertilisasi Invitro Sapi (Role of $\mathrm{NaHCO}_{3}$ buffer in $\mathrm{BO}$ medium in inducing capacitance, acrosome reaction, sperm viability, and sperm penetration of oocytes in vitro fertilization of cattle). Jurnal IImu-IImu Hayati (Journal of the Biological Sciences), Vol. 6(1) (in Indonesian)

Djauhari, T. (2009). Pengaruh Penambahan Fosfolipid Terhadap Kualitas Spermatozoa Manusia (Effects of addition of phospholipids on the quality of human spermatozoa). Saintika Medika: Jurnal IImu Kesehatan dan Kedokteran Keluarga (Saintika Medika: Journal of Health and Family Medicine), Vol. 5(2) (in Indonesian)

Dragileva, E., Rubinstein, S. \& Breitbart, H. (1999). Intracellular $\mathrm{Ca} 2+-\mathrm{Mg} 2+-$ ATPase regulates calcium influx and acrosomal exocytosis in bull and ram spermatozoa. Biol. Reprod., Vol. 61: 1226-1234.

Ellis-Davies, G.C. \& Kaplan; J.H. (1994). Nitrophenyl-EGTA, a photolabile 


\section{ANALYSIS OF SPERMATOZOA QUALITY USING PERCOLL DENSITY GRADIENT CENTRIFUGATION}

chelator that selectively binds $\mathrm{Ca} 2+$ with high affinity and releases it rapidly upon photolysis. Proc. Natl. Acad. Sci., 91(1): 187-191, DOI: 10.1073/pnas. 91.1.187

Garner, D.L. \& Hafez., E.S.E (2000). Spermatozoa and seminal plasma. In: Reproduction in Farm Animals $\left(7^{\text {th }}\right.$ ed.), Hafez, B., Hafez, E.S.E. (Eds.), Lea and Febiger, Philadelphia, pp. 96-109.

Hafez, E.S.E. (2000). X- and Y- chromosomebearing spermatozoa. In: Reproduction in Farm Animals ( $7^{\text {th }}$ ed.), Lea \& Febiger, Philadelphia, pp. 440-446.

Hu, Q., Corda, S., Zweier, J.L., Capogrossi, M.C. \& Ziegelstein, R.C. (1988). Hydrogen peroxide induces intracellular calcium oscillation in human aortic endothelial cells. Circulation, 97(3): 268-275, DOI: 10.1161/01.cir.97.3.268

Lemonnier, L., Vitko, Y., Shuba, Y.M., Abeele, F.V., Prevarskaya, N. \& Skryma, R. (2002). Direct modulation of volume-regulation anion channels by Ca2+ chelating agents. FEBS Letter, 521: 152-156.

Parekh, A.B. (2002). The welcome prize lecture. Store-operated $\mathrm{Ca} 2+$ entry: dynamic interplay between endoplasmic reticulum, mitochondria and plasma membrane. J Physiology., 547: 333-348, DOI: 10.1113/jphysiol.2002.034140

Rasad, S.D., Setiawan, R., Solihati, N., Widyastuti, R. dan Nugraha, I. (2019). Derajat Pemulihan dan Persentase Spermatozoa $X$ dan $Y$ Kambing Peranakan Etawah Setelah Separasi dengan Gradient Percoll (Degree of recoverand percentage of spermatozoa $X$ and $Y$ Etawah Crossbreeds after separation with Percoll gradients). Jurnal Veteriner (Veterinary Journal). Vol. 20(1): 14-19 (in Indonesian).

Rumende, R.R.H., Kalim, H., Widodo, A. dan Djati, M.S. (2007). Peningkatan Kualitas Spermatozoa Sapi pada Proses Pemisahan Kromosom $X$ dan $Y$ dengan Sentrifugasi Gradien Densitas Percoll Melalui Pemberian Fosfolipid
(Improving the quality of bovine spermatozoa in the separation process of $X$ and $Y$ chromosomes by centrifugation of Percoll density gradients by giving phospholipids). Jurnal Kedokteran Brawijaya (Brawijaya Medical Journal). Vol. 23(2): 71-81 (in Indonesian).

Sadova, M., Klishin, A., Huser, J. \& Blatter, L.A. (2000). Capacitative calcium entry is graded with degree of intracellular calcium store depletion in bovine vascular endothelial cells. J. Physiol., 523(Pt 3): 549-559, DOI: 10.1111/ j.1469-7793.2000.t01-3-00549.x

Susilawati, T., Kusumawati, E.D., Isnaini, N., Yekti, A.P.A, Sudarwati, H. \& Ridhowi, A. (2017). Effect of sexing process using Percoll density gradient centrifugation and frozen on motility and damage to spermatozoa membrane of Filial Ongole. Atlantis Press, Brawijaya University, Malang, Indonesia.

Toole, Ch., Roldan, M.B.O., Hampton, E.R.S. \& Fraser, P. (1996). A role for diacylgycerol in human sperm acrosomal exocytosis. Mol. Hum. Reprod., 2(5): 317-326.

Tucker, K.E. \& Jansen, C.A.M. (2002). Sperm separation techniques: comparison and evaluation of gradient product. In: Proceedings $2^{\text {nd }}$ International Workshop for Embryologists: Troubleshooting Activities in the ART Lab., R. Basuray and D Mortimer (Eds.).

Zanella, E., Zanella, R., Poetini, M.R., Marques, M.G., Soares, J.C.M. \& Bondan, C. (2016) Oxidative status of boar semen during storage. Am. J. Biochem. Biotechnol., 12(2): 95-101, DOI: 10.3844/ajbbsp.2016.95.101

Zenichiro, K., Herliante dan Sarastina (2002). Intruksi Praktis Teknologi Prosesing Semen Beku pada Sapi. (Technology of frozen semen processing for cattle). Balai Besar Inseminasi Buatan Singosari, Malang, Indonesia. 